\title{
HIGH RESISTIVITY AlGaAs GROWN BY LOW TEMPERATURE MBE
}

\author{
D. Radomska, J. RatajczaK, K. RegińsKi and M. BugajSKi
}

Institute of Electron Technology, Al. Lotników 32/46, 02-668 Warsaw, Poland

\begin{abstract}
$\mathrm{Al}_{0.3} \mathrm{Ga}_{0.7}$ As layers were grown by molecular beam epitaxy using substrate temperature $200-300^{\circ} \mathrm{C}$, tetrameric As and two values of $\mathrm{As} / \mathrm{Ga}+\mathrm{Al}$ flux ratio i.e. 3 or 8 . The post-growth annealing was performed in situ at $600^{\circ} \mathrm{C}$ for $20 \mathrm{~min}$ under As-overpressure. The samples were characterised by reflection high-energy electron diffraction, transmission electron microscope and room-temperature $I-V$ measurements of $n^{+} / \mathrm{LT}$ grown layer $/ n^{+}$resistors. The resistivity and trap-filled limited voltage have been determined. The best layers exhibited $\rho$ of the order of $10^{9} \Omega \mathrm{cm}$, were monocrystalline, uniformly precipitated and without dislocations.
\end{abstract}

PACS numbers: 73.61.Ey

\section{Introduction}

It is commonly known that molecular beam epitaxy (MBE) of GaAs and AlGaAs at significantly reduced substrate temperature $\left(200-300^{\circ} \mathrm{C}\right)$ results in non-stoichiometric material with 1-2\% excess As atoms [1,2]. An incorporation of As into the crystal lattice is strongly dependent on the growth conditions. Upon a proper thermal treatment, excess arsenic precipitates and low temperature (LT) grown layers become semi-insulating. Compared to $\mathrm{SiN}_{x}$ and $\mathrm{SiO}_{2}$ they present much better matching of the thermal expansion coefficient and thermal conductivity to GaAs and are suitable for overgrowth. These make LT GaAs and AlGaAs potentially very useful for current-blocking layers in electronic and optoelectronic devices. In addition, LT AlGaAs as a material with low refractive index would be able to provide in combination with GaAs both electrical isolation and waveguiding effect.

This study was undertaken in order to establish MBE growth conditions for obtaining AlGaAs layers having good insulating properties, without extended defects and well oriented surface. This is not a trivial task because of the critical thickness for dislocations formation and the lack of a precise method to measure substrate temperature in the temperature range below $450^{\circ} \mathrm{C}$. We have continued our earlier works on low temperature grown GaAs $[3,4]$. 


\section{Experiment}

The layers used in this study were grown in MBE Riber 32P system on (100) oriented $n^{+}$-GaAs substrates with a tetrameric arsenic source. The typical growth rate of $1 \mu \mathrm{m} / \mathrm{h}$ was used, calibrated at $590^{\circ} \mathrm{C}$ from reflection high-energy electron diffraction (RHEED) oscillations. The substrates were mounted to molybdenum blocks using indium solder. Prior to the growth the wafers were outgassed at $430^{\circ} \mathrm{C}$ without arsenic for $30 \mathrm{~min}$ and the oxide was desorbed by heating under As overpressure up to $630^{\circ} \mathrm{C}$. The $0.5 \mu \mathrm{m}$ thick GaAs:Si $\left(2 \times 10^{18} \mathrm{~cm}^{-3}\right)$ buffer was grown followed by the $10 \mathrm{~nm} \mathrm{GaAs:Si}\left(2 \times 10^{16} \mathrm{~cm}^{-3}\right)$ spacer. Then the growth was terminated and substrate temperature decreased to the low temperature range $200-300^{\circ} \mathrm{C}$. The undoped $0.5 \mu \mathrm{m} \mathrm{Al}_{0.3} \mathrm{Ga}_{0.7} \mathrm{As}$ layer was deposited. We chose two values of the group $\mathrm{V}$ to group III flux ratio 3 or 8 . The growth was interrupted once again and samples were heated while temperature reached $600^{\circ} \mathrm{C}$. LT layer was annealed for $10 \mathrm{~min}$ under As overpressure to ensure $(2 \times 4)$ As-stabilised surface and then capped with the $10 \mathrm{~nm}$ thick GaAs:Si $\left(2 \times 10^{16} \mathrm{~cm}^{-3}\right)$ spacer and $200 \mathrm{~nm}$ of GaAs:Si $\left(2 \times 10^{18} \mathrm{~cm}^{-3}\right)$ contact layer. Thus, the total time of post-growth annealing treatment was $22.5 \mathrm{~min}$.

To test the role of interfaces GaAs/AlGaAs in complex structures, a certain modification of the geometry of LT region was introduced in the sample \# 261 (Fig. 1).

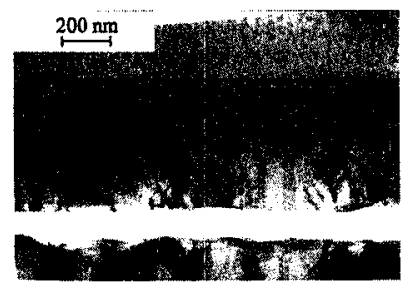

Fig. 1. Transmission electron microscope (TEM) cross-section of the sample \#261. The $\mathrm{LT}$ region consists of three $\mathrm{LT} \mathrm{Al}_{0.3} \mathrm{Ga}_{0.7}$ As layers separated by LT GaAs. The critical thickness is exceeded. Apart from precipitates, the dislocations are seen.

Resistors were made by forming top and bottom $\mathrm{Au} / \mathrm{Ge} / \mathrm{Ni}$ alloyed ohmic contacts and defining by standard photolithography and dry etching circular mesas of diameter of $200 \mu \mathrm{m}$.

The big problem in MBE system for III-V compounds is precise substrate temperature control for the low temperature range. Below $450^{\circ} \mathrm{C}$ an infrared pyrometer does not work and reading of the temperature is possible only by means of the thermocouple which is placed at the bottom of molyblock. We have calibrated our thermocouple against indium melting point $\left(157^{\circ} \mathrm{C}\right)$ and by an infrared Ircon- $\mathrm{V}$ type pyrometer in the range $450-630^{\circ} \mathrm{C}$. The calibrations were done for each of used molybdenum blocks. An influence of the opened $\mathrm{Ga}$ and $\mathrm{Al}$ effusion cells has been taken into account. We have found that at $200^{\circ} \mathrm{C}$ a substrate temperature rise due to the radiation from $\mathrm{Ga}$ and $\mathrm{Al}$ cells is $55-75^{\circ} \mathrm{C}$ depending on the state of molyblock. 
During the growth, the surface of the samples has been probed during using RHEED. We observed the following evolution of a diffraction pattern. The layers grown at standard temperatures, 585 and $600^{\circ} \mathrm{C}$, exhibited the standard $(2 \times 4)$ reconstruction. On cooling down, the reconstruction changed into $(2 \times 2)$ at about $480^{\circ} \mathrm{C}$. As soon as the group III beams were switched on, the surface lost immediately the reconstruction and showed the $(1 \times 1)$ pattern. After closing the $\mathrm{Al}$ and $\mathrm{Ga}$ shutters the twofold reconstruction returned. Annealing caused a recovery of the clear $(2 \times 4)$ pattern suggesting an improvement in the crystal quality. The layers griown at the highest of chosen temperatures i.e., $300^{\circ} \mathrm{C}$, demonstrated the $(2 \times 4)$ pattern before annealing.

\section{Results and discussion}

The current blocking properties were determined by resistivity and trap-filled limited voltage (an intersection point of the linear and "trap-filled" regions of the $\log -\log I-V$ curve) extracted from room-temperature current-voltage characteristics. These parameters and the growth conditions are compared in Table. Generally, LT AlGaAs shows three orders of magnitude higher resistivity than that obtained for LT GaAs.

TABLE

Comparison of crystal and electrical properties of the resistor structures including the $\mathrm{LT} \mathrm{Al}_{0.3} \mathrm{Ga}_{0.7}$ As layer grown at different substrate temperatures and III/V flux ratios.

\begin{tabular}{c|c|c|c|c|c}
\hline \hline Sample & $\begin{array}{c}\text { Growth temp. } \\
{\left[{ }^{\circ} \mathrm{C}\right]}\end{array}$ & $\begin{array}{c}\text { V/III flux } \\
\text { ratio }\end{array}$ & $\begin{array}{c}\text { Thickness of } \\
\text { LT layer } \\
{[\mathrm{nm}]}\end{array}$ & $\begin{array}{c}\rho \\
\text { at } 2.5 \mathrm{~V} \\
{[\Omega \mathrm{cm}]}\end{array}$ & $\begin{array}{c}V_{\mathrm{tf}} \\
{[\mathrm{V}]}\end{array}$ \\
\hline$\# 254$ & 200 & 3 & 500 & $4.2 \times 10^{7}$ & 11 \\
$\# 261$ & 220 & 8 & 308 & $1.1 \times 10^{8}$ & $6^{*}$ \\
$\# 255$ & 250 & 3 & 500 & $3.0 \times 10^{7}$ & 17 \\
$\# 256$ & 250 & 8 & 500 & $5.9 \times 10^{7}$ & 17 \\
$\# 265$ & 300 & 3 & 500 & $8.5 \times 10^{8}$ & 10 \\
$\# 266$ & 300 & 8 & 500 & $3.7 \times 10^{9}$ & 10 \\
\hline
\end{tabular}

*Note that the LT layer is thinner than in other structures.

Some contradiction with respect to $\rho$ and $V_{\mathrm{tf}}$ is seen. The $250^{\circ} \mathrm{C}$ grown layers exhibit much higher $V_{\mathrm{tf}}$ than the $300^{\circ} \mathrm{C}$ grown ones, but lower resistivity. The same behaviour have been observed by Verma et al. [5] and was explained by residual hopping conduction in the material grown at $250^{\circ} \mathrm{C}$.

In the TEM pictures (Fig. 2) As precipitates in the buffer layer are visible. This is the evidence that the arsenic diffusion occurred during the annealing. To prevent this, AlAs confining layers or AlAs/GaAs superlattices should be applied to inhibit this phenomenon [6]. 


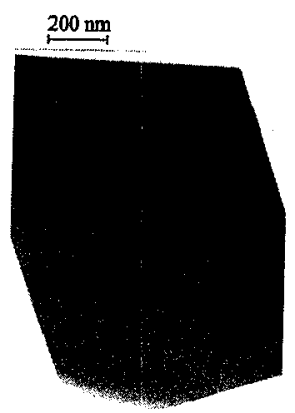

Fig. 2. Cross-sectioned TEM picture of the sample \#265. The interfaces are planar and the layer uniformly precipitated. Extended defects are not present. Note the precipitates in the buffer layer.

We have not done detailed investigations of the critical thickness for dislocation formation. However, we have observed that when the growth temperature exceeded about $230-240^{\circ} \mathrm{C}$ an abrupt increase in the critical thickness occurred (from about $30 \mathrm{~nm}$ at $220^{\circ} \mathrm{C}$ to above $500 \mathrm{~nm}$ at $250^{\circ} \mathrm{C}$ for $\mathrm{V} / \mathrm{III}$ flux ratio of 3 ). This is in agreement with earlier findings reported by Eaglesham et al. [7].

The values of $\rho$ and $V_{\mathrm{tfl}}$ from Table and $I-V$ characteristics (not presented here) point out that all LT AlGaAs layers obtained in our experiments are effective in providing the current blocking. However, only those grown at $250^{\circ} \mathrm{C}$ and $300^{\circ} \mathrm{C}$ have structural quality suitable for device applications i.e. they are monocrystalline, uniformly precipitated, without dislocations and with the smooth surface.

\section{Summary}

$\mathrm{Al}_{0.3} \mathrm{Ga}_{0.7} \mathrm{As}$ layers were grown by molecular beam epitaxy at substrate temperatures $200-300^{\circ} \mathrm{C}$, using tetrameric $\mathrm{As}$ and two values of $\mathrm{As} / \mathrm{Ga}+\mathrm{Al}$ flux ratio i.e. 3 or 8 . Very high resistivities of the order of $10^{8}-10^{9} \Omega \mathrm{cm}$ and high breakdown voltages: $10-18 \mathrm{~V}$ for $500 \mathrm{~nm}$ thick layers, have been obtained. This is the substantial improvement of insulating properties comparing to LT GaAs for which $10^{6} \Omega \mathrm{cm}$ resistivity are typical. The best results in terms of electrical parameters have been obtained for the growth temperature of $250^{\circ} \mathrm{C}$ and the highest V/III flux ratio. The crystal quality of the layers was monitored in situ by RHEED. Transmission electron microscope studies showed that LT AlGaAs is monocrystalline, uniformly precipitated and free of extended defects and dislocations.

\section{Acknowledgment}

This work was supported by grant no. 8T11B00712 and PBZ28.11/P7 of the Committee for Scientific Research.

\section{References}

[1] D.C. Look, Thin Solid Films 231, 61 (1993).

[2] T.Y. Chu, A. Dodabalapur, A. Srinivasan, D.P. Niikirk, B.G. Streetman, J. Cryst. Growth 11, 26 (1991). 
[3] K. Regiński, A. Malag, D. Radomska, M. Bugajski, Proc. IEEE SIMC-9, p. 333, 1996.

[4] K. Regiński, A. Maląg, D. Radomska, J. Kątcki, J. Muszalski, M. Bugajski, W. Strupiński, Electron Technol. 29, 387 (1996).

[5] K. Verma, I. Tu, J.S. Smith, H. Fujioka, E.R. Weber, J. Electron. Mater. 22, 1417 (1993).

[6] J.P. Ibbeson, C.R. Bolognesi, H. Weman, A.C. Gossard, U.K. Mishra, in: Gallium Arsenide and Related Compounds, Ed. B.B. Stringfellow, Inst. Phys. Conf. Ser. No. 120, Washington 1991 , p. 37.

[7] D.J. Eaglesham, L.N. Pfeiffer, K.W. West, D.R. Dykaar, Appl. Phys. Lett. 58, 65 (1991). 